\title{
Emergence of ITD tuning in the MSO with a realistic periphery model
}

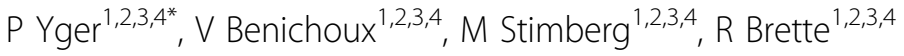 \\ From 24th Annual Computational Neuroscience Meeting: CNS*2015 \\ Prague, Czech Republic. 18-23 July 2015
}

To localize sounds in the environment, animals mostly rely on spectro-temporal cues originating from the physical disparities of the sound waveforms impacting the two ears. Among those, the Interaural Time Difference (ITD) has been shown to be crucial in mammals for locating low-frequency sounds, and is known to be processed by neurons in a particular structure, the Medial Superior Olive (MSO). While it is classically considered that the emergence of ITD selectivity in a neuron of the MSO is simply due to differences in the axonal delays originating from the two ears and impinging those neurons (the so called "delay-line" model [1]), experimental evidence shows that the best delay (the ITD at which the neuron's firing rate is maximum) is also dependent on the frequency of the sound [2].

To investigate more on this challenging experimental observation, we developed a realistic periphery model to mimic cochlear inputs from auditory nerves fibers onto the MSO. Using known plasticity rules such as Spike Timing Dependent Plasticity to structure the wiring from those connections onto the MSO, we extend the work that has already been performed [3], and study the emergence of binaural tuning in the MSO in a realistic scenario. The system is trained with binaural sounds such as white noise, and then, as in most experimental papers, we tested the ITD selectivity of cells in the MSO by presenting pure tones at various frequencies.

Finally, we discuss, from a coding point of view the potential implications raised by the frequency dependence of the best delay. As pointed out by recent work [4], with such a frequency-dependent best delay, neurons in the MSO should be seen as coding for a

\footnotetext{
* Correspondence: pierre.yger@inserm.fr

'Institut d'Etudes de la Cognition, Ecole Normale Supérieure, Paris, France
} Full list of author information is available at the end of the article particular position in space, rather than for just a fixed delay difference.

\section{Acknowledgment}

This work is funded with a Fellowship Grant from the FRM (Fondation pour la Recherche Médicale), and the European Research Council (StG 240132)

\section{Authors' details}

${ }^{1}$ Institut d'Etudes de la Cognition, Ecole Normale Supérieure, Paris, France. ${ }^{2}$ Sorbonne Universités, UPMC Univ. Paris 06, UMR S 968, Institut de la Vision, Paris, F-75012, France. ${ }^{3}$ INSERM, U968, Paris, F-75012, France. ${ }^{4}$ CNRS, UMR 7210, Paris, F-75012, France.

Published: 18 December 2015

\section{References}

1. Jeffress LA: A place theory of sound localization. J Comp Physiol Psychol 1948, 41(1):35-39.

2. Joris $P$, Yin TC: A matter of time: internal delays in binaural processing. Trends Neurosci 2007, 30(2):70-78.

3. Fontaine B, Brette R: Neural Development of Binaural Tuning through Hebbian Learning Predicts Frequency-Dependent Best Delays. J Neurosci 2011, 31(32):11692-11696.

4. Benichoux V, Fontaine B, Karino S, Joris P, Brette R: Frequency-dependent time differences between the ears are matched in neural tuning (in revision).

doi:10.1186/1471-2202-16-S1-P20

Cite this article as: Yger et al:: Emergence of ITD tuning in the MSO with a realistic periphery model. BMC Neuroscience 2015 16(Suppl 1):P20.

\section{Submit your next manuscript to BioMed Central and take full advantage of: \\ - Convenient online submission \\ - Thorough peer review \\ - No space constraints or color figure charges \\ - Immediate publication on acceptance \\ - Inclusion in PubMed, CAS, Scopus and Google Scholar \\ - Research which is freely available for redistribution \\ Submit your manuscript at www.biomedcentral.com/submit}

C Biomed Central

(c) 2015 Yger et al. This is an Open Access article distributed under the terms of the Creative Commons Attribution License (http:// creativecommons.org/licenses/by/4.0), which permits unrestricted use, distribution, and reproduction in any medium, provided the original work is properly cited. The Creative Commons Public Domain Dedication waiver (http://creativecommons.org/publicdomain/ zero/1.0/) applies to the data made available in this article, unless otherwise stated. 